\title{
Evolution of 3-D Geologic Framework Modeling and Its Application to Groundwater Flow Studies
}

\author{
In this Fact Sheet, the authors discuss \\ the evolution of project 3-D subsurface \\ framework modeling, research \\ in hydrostratigraphy and airborne \\ geophysics, and methodologies \\ used to link geologic and \\ groundwater flow models.
}

\section{7 he various geologic processes that shape the Earth's surface and sub-} surface all operate in three-dimensional (3-D) space. Within the U.S. Geological Survey (USGS), the greatest needs and applications for 3-D modeling include the following: (1) visualization of surface geology into the subsurface, (2) interpretation and verification of the geology and its controlling fault structures, and (3) application of 3-D model data for investigating geologic issues (Jacobsen and others, 2011).

Three-dimensional geologic modeling of an aquifer can quantitatively depict the connectedness of rock units across fault and fracture zones. This modeling allows geologists to determine the distribution of geologic units, structural features, and other controlling factors, such as porosity and permeability. These parameters are complex variables that reflect original depositional conditions, alteration, dissolution, and dislocation. Geologic 3-D framework modeling also is useful for visualizing the interactions of fault and related structural features.

\footnotetext{
Ratio of the volume of voids in a porosity material to the total volume of the porous medium

permeability Rate of flow of a fluid through a porous material

Freely available USGS computer

MODFLOW software to simulate the flow of groundwater through aquifers
}

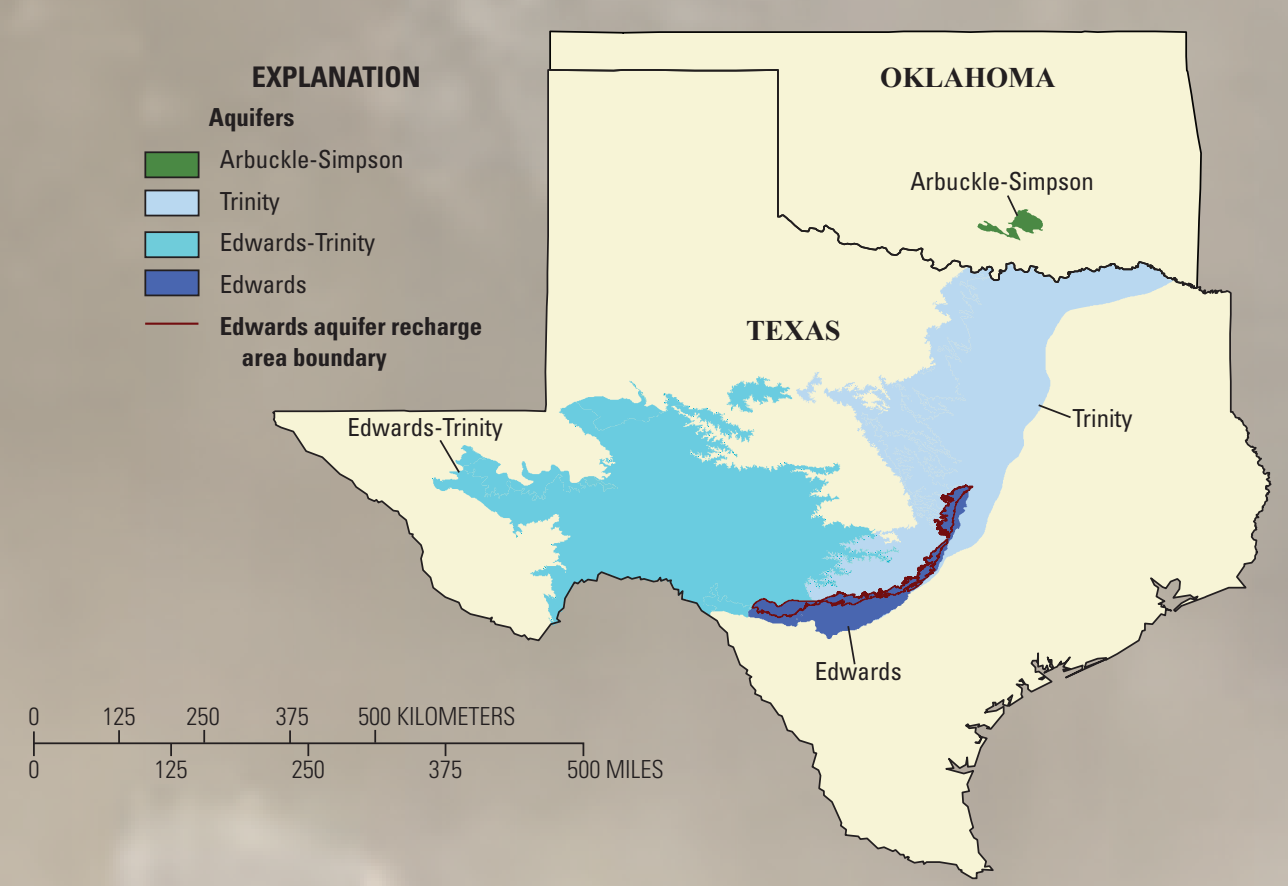

Figure 1. Location map of the Arbuckle-Simpson and Trinity aquifers and Edwards aquifer recharge area.

Three-dimensional geologic framework models can be directly converted into groundwater flow models, such as MODFLOW. Construction of the 3-D geologic architecture of an aquifer needs to be the first step in using geologic properties to constrain groundwater flow models. This first-step approach takes much of the subjective guesswork out of constructing model layers and results in a model that is more realistic and representative of the actual subsurface hydrologic conditions of the groundwater basin being modeled.

Several USGS projects, supported by the National Cooperative Geologic Mapping Program (NCGMP), are using multidisciplinary approaches to reveal the surface and subsurface geologic framework of three important groundwater aquifers: the Edwards, Trinity, and Arbuckle-Simpson (fig. 1). In this Fact Sheet, the authors discuss the evolution of project 3-D subsurface framework modeling, research in hydrostratigraphy and airborne geophysics, and methodologies used to link geologic and groundwater flow models. The principal sections of this Fact Sheet are as follows:

1 Geologic Framework of the Edwards and Trinity Aquifers

2 Geologic Framework of the Arbuckle-Simpson Aquifer

3 Arbuckle-Simpson 3-D Geologic Framework Model to Groundwater Flow Model

4 Arbuckle-Simpson MODFLOW Model 
1 Geologic Framework of the Edwards and Trinity Aquifers

The Edwards aquifer in Texas is one of the most productive freshwater quifers in the world. It has been designated a sole source aquifer by the U.S. Environmental Protection Agency (EPA) and is the primary source of water for San Antonio, the Nation's seventh largest city. Understanding the Edwards is . The Trinity aquifer forms the catchment area for the Edwards aquifer, and it intercepts some surface flow above the Edwards recharge area. The Trinity aquifer also may contribute to the Edwards' water budget by subsurface flow across formation boundaries at considerable depths. Dissolution, karst development, an faulting and fracturing in both of these carbonate-rich aquifers directly control aquifer geometry by compartmentalizing the aquifer and creating unique groundwater flow paths.

Three-dimensional modeling studies of aquifer-bearing units in south-central Texas concentrated on the area's carbonate-rich hydrostratigraphic units, and underscored the importance of airborne electromagnetic data for defining new unit contacts and fault structures (Blome and others, 2006). Two 3-D models discussed as follows highlight key controls on aquifer permeability and provide insights on subsurface aquifer processes and aquifer boundaries and interfaces. The proprietary software Earth Vision (EV) was used because of its ability to combine various data types and accurately define faulted surfaces while maintaining stratigraphic and structural integrity and complexity.

The 3-D EV model of northern Bexar County (fig. 2) reveals the subsurface geology and groundwater flow units of the Edwards and Trinity aquifers, where water wells range from 60 to over 300 meters in depth. This 3-D mode is based on mapped geologic relations tha reflect: (1) Balcones faull zone structures, and (3) gross geometry of the Edwards Group hydrostratigraphic units derived from prior interpretations of depositional environments and paleogeography. The 3-D model was also constructed to determine whether hydrostratigraph units could be accurately modeled in the subsurface and to visualize the lateral connection between hydrostratigraphic units of contrasting permeability across fault strands.

A 3-D EV model of the rock units of the Edwards and Trinity Groups in the north Seco Creek area of Medina and Uvalde Counties, Texa (fig. 3), was constructed using a variety of digital datasets, such as: (1) geologic maps, including the current geologic map of the area (Blome and others, 2004), (2) liklogic desciptions, interpre(3) helicopter electromagnetic geophysichl des; (Smith and others, 2003): and (4) known maja (Sinor faults in the study area This model reveal the complex intersections of both major and min faults in the subsurface, and the impact these faults have on the continuity of the Trinity and Edwards aquifer-forming units.

\section{Body of rock that forms a
disintect hydrologic cunit with
the flow of groundwater Ability to emit or transfer
energy in the form of} to construct the model.

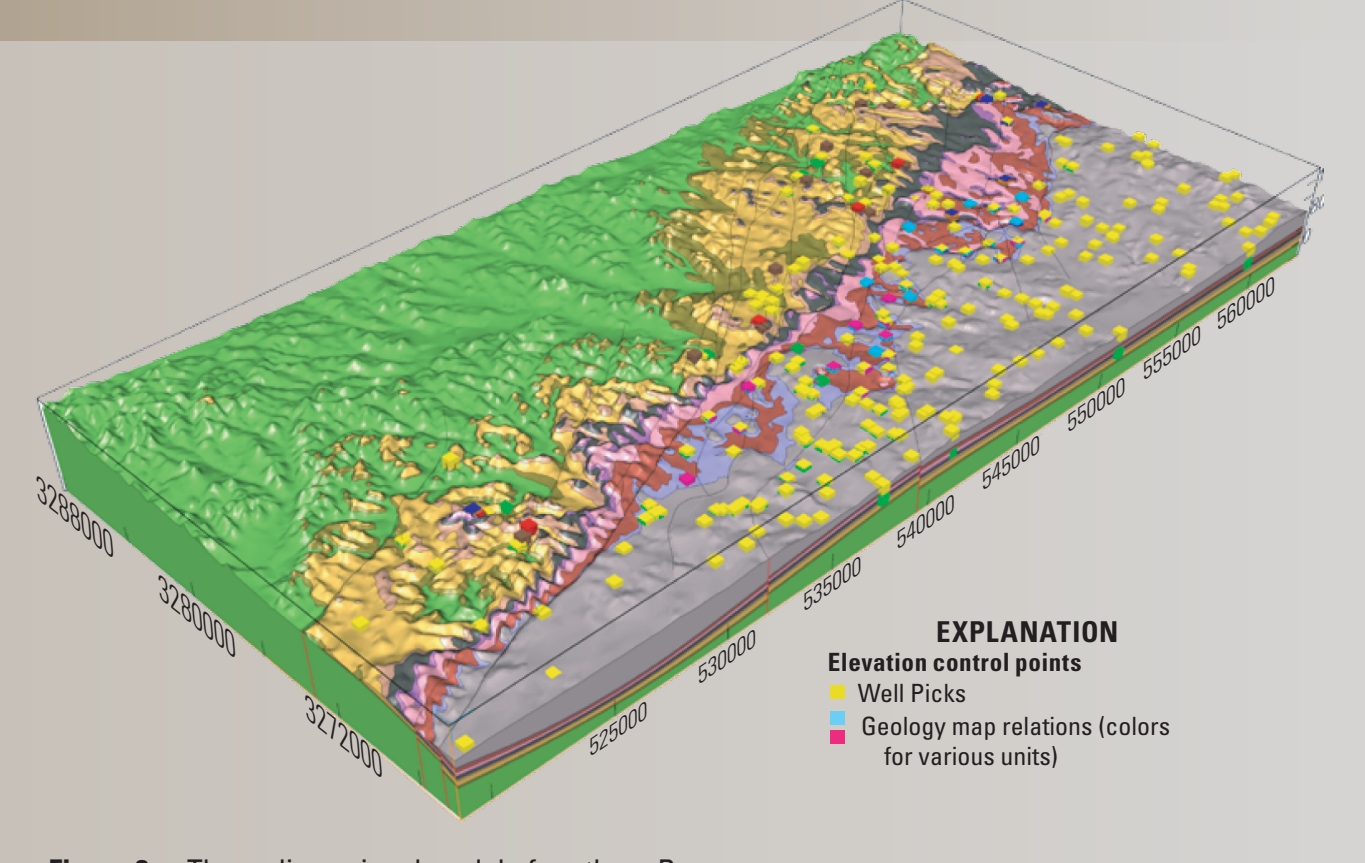
Figure 2. Three-dimensional model of northern Bexar

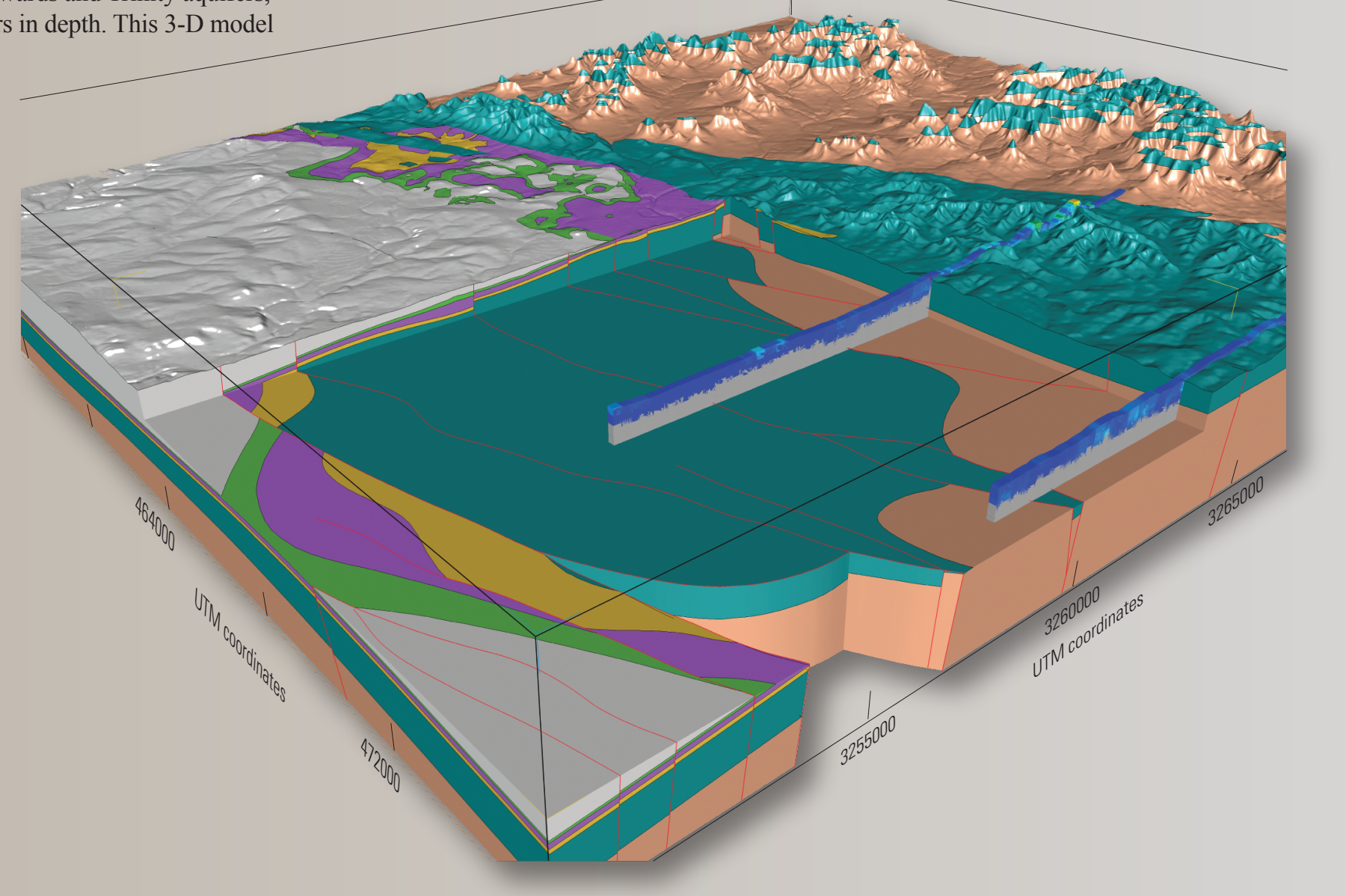

Figure 3. Three-dimensional model of the north Seco Creek area of Medina and Uvalde Counties, Texas (Pantea and others, 2008). Multiple fault structures (shown in red)

\section{Geologic Framework of the Arbuckle-Simpson Aquifer}

The Arbuckle-Simpson aquifer of south-central Oklahoma (fig. 1) encompasses more than 850 square kilometers and provides water for public drinking supply, farming, mining, conservation, and recreation. The aquifer also contains a number of unique freshwater and mineral springs, such as Buffalo spring (fig. 4), in the Chickasaw National Recreation Area.

The aquifer's eastern groundwater basin (Hunton anticline area, fig. 5) has been designated a sole source aquifer by the EPA. Proposed development of water supplies from the aquifer led to concerns that large-scale withdrawals of water would cause decreased flow in rivers and springs, which in t

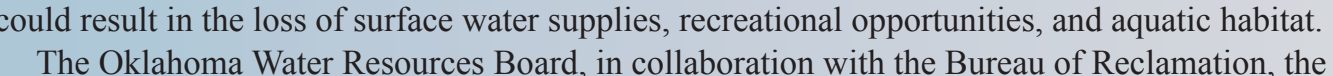
USGS, Oklahoma State University, and the University of Oklahoma studied the aquifer to determine the volume of water that could be withdrawn while protecting springs and streams. The USGS with the USGS Oklahoma Water Science Center and other Federal and State agencies, supported framewo water-producing Hunto water-producing Hunton anticline area. Construction of the model was challenging due to the folded,
faulted, and fractured nature of the Hunton anticline geology (fig. 5), variable unit thicknesses (from 600 to 2,750 meters), and scarcity of well information

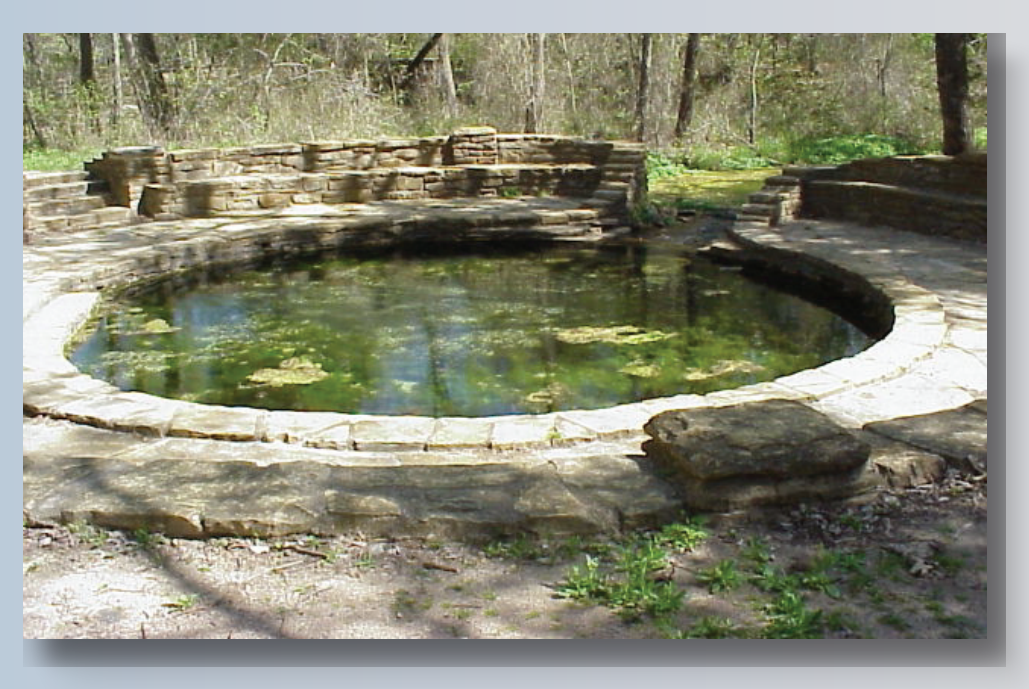

Figure 4.
Oklahoma

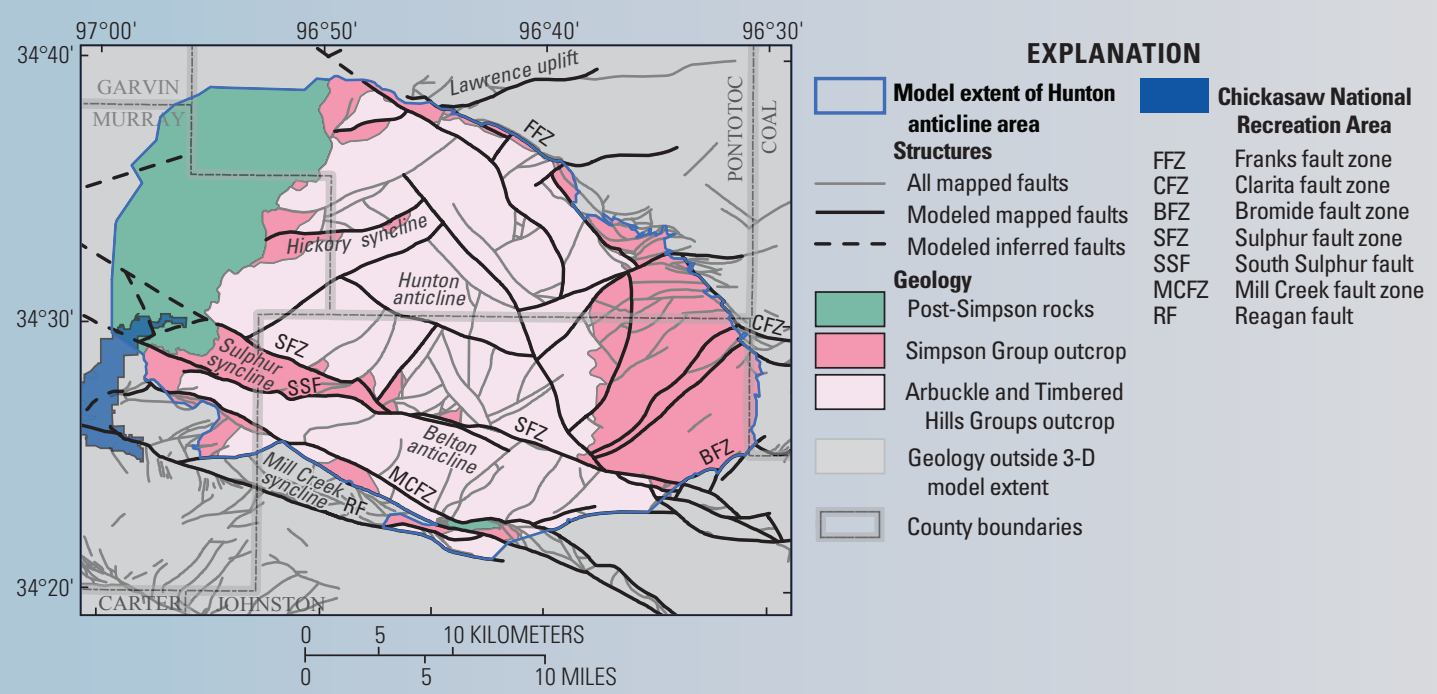

Figure 5. Geology of the Arbuckle-Simpson aquifer's Hunton anticline area, south-central 0klahoma (outlined in blue), and its major and minor fault structures (Faith and others, 2010). 
This 3-D framework model was constructed to quantify the geometric relations of four hydrostratigraphic units of the Arbuckle-Simpson aquifer in the Hunton anticline area (Faith and others, 2010). The model (fig. 6) shows the volumetric extents of the Arbuckle and Timbered Hills Groups (light pink) and Simpson Group (dark pink) rocks, which are the primary water-bearing units of the aquifer. The data used to define the model and modeled surfaces were obtained from geophysical logs, cores, and cuttings from 126 water and petroleum wells.

The model stratigraphic contacts and faults were defined from the surface geologic mapping by Johnson (1990) and the geospatial map database of Cederstrand (1996). The top of the basement was defined using data from 13 drill holes. The top of the Arbuckle-Timbered Hills Group was picked from 89 drill holes and represents the model's primary reference surface, which was used to define other model surfaces. The top of the Simpson Group was identified in 54 wells. Locally, pre-erosional surfaces for the Simpson Group and basement model units were projected based on the $\mathrm{x}-, \mathrm{y}-$, and $\mathrm{z}$-values of a known contact. The post-Simpson model unit was defined as the volume between the top of the Simpson Group and the surface of the digital elevation model. Over much of the model area, post-Simpson rocks are missing because of erosion.

Geophysical data, including a helicopter electromagnetic survey (Smith and others, 2011), were used as follows: (1) to precisely locate mapped faults, (2) to identify shallow faults that have no recognizable surface expression, (3) to refine the outcrops of the lithostratigraphic units, and (4) to map the transition between freshwater springs in the east and saline springs in the west. A map of apparent resistivity over one survey block on the southwestern flank of the Hunton anticline (fig. 7) represents rock units with clarity and detail unachievable by using traditional field geology mapping techniques.

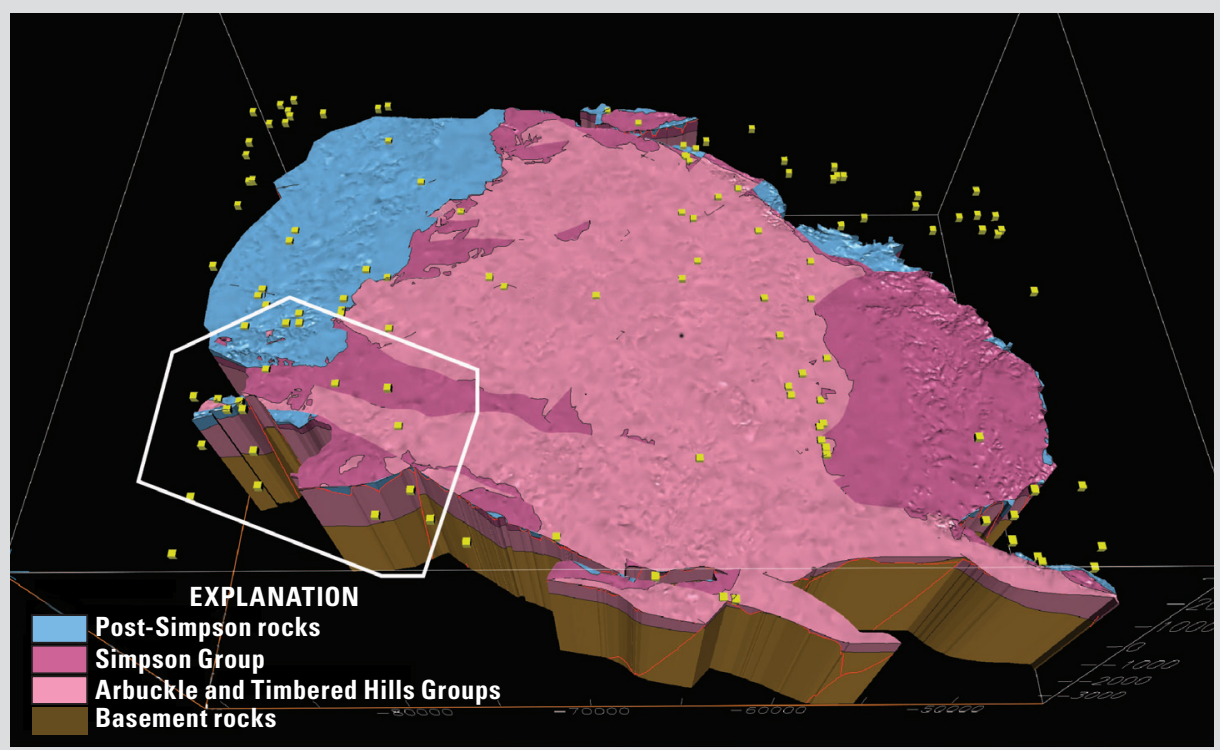

Figure 6. A perspective view of the 3-D geologic framework model of the Arbuckle-Simpson aquifer (Faith and others, 2010). The yellow boxes represent the wells used to construct the model. The white polygon outlines the area of the helicopter electromagnetic survey shown in figure 7.

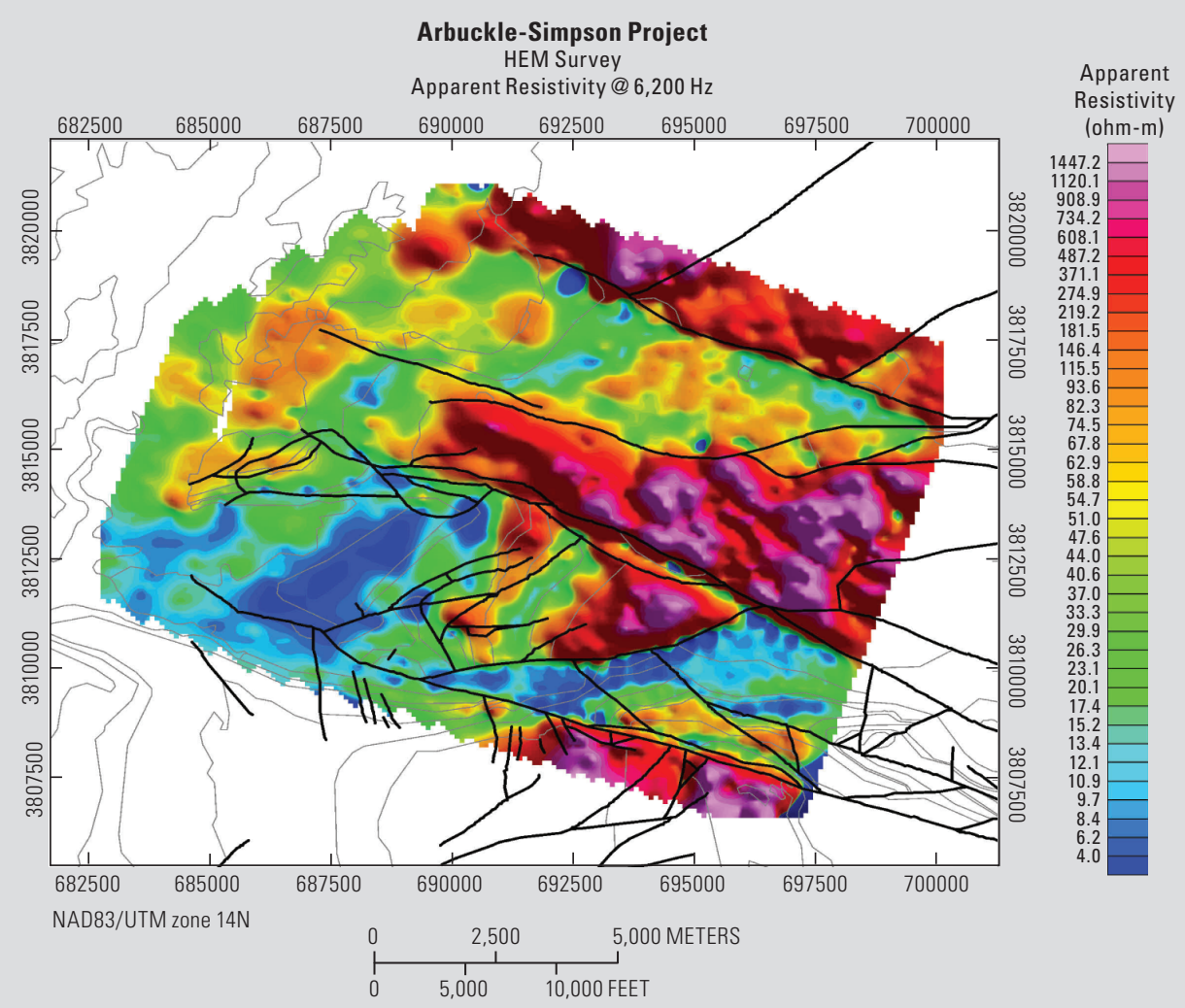

Figure 7. Apparent resistivity map from the helicopter electromagnetic survey on the southwestern flank of the Hunton anticline (Smith and others, 2011). Previously mapped geologic contacts and faults are shown as gray and black lines, respectively. 


\section{Arbuckle-Simpson 3-D Geologic Framework Model
to Groundwater Flow Model}

The boundary of the 3-D EV model of the eastern Arbuckle-Simpson aquifer model developed by the USGS as part of the Arbuckle-Simpson Hydrology Study, which was led by the Oklahoma Water Resources Board and the USGS Oklahom Water Science Center. Hydrostratigraphic surfaces in EarthVision were sampled and interpolated to match nodes in the MODFLOW model. These nodes provide the land-surface elevations and the thick-
nesses of the Arbuckle and Timbered Hills nesses of the Arbuckle and Timbered
Groups, Simpson Group, and the postGroups, Simpson Group, and the post-
Simpson units across the entire MODFLOW model domain. The Arbucke and Timberd Hills Groups make up the major part of the quifer for hickness, outcop extent, and volume of groundwater (fig. 8).
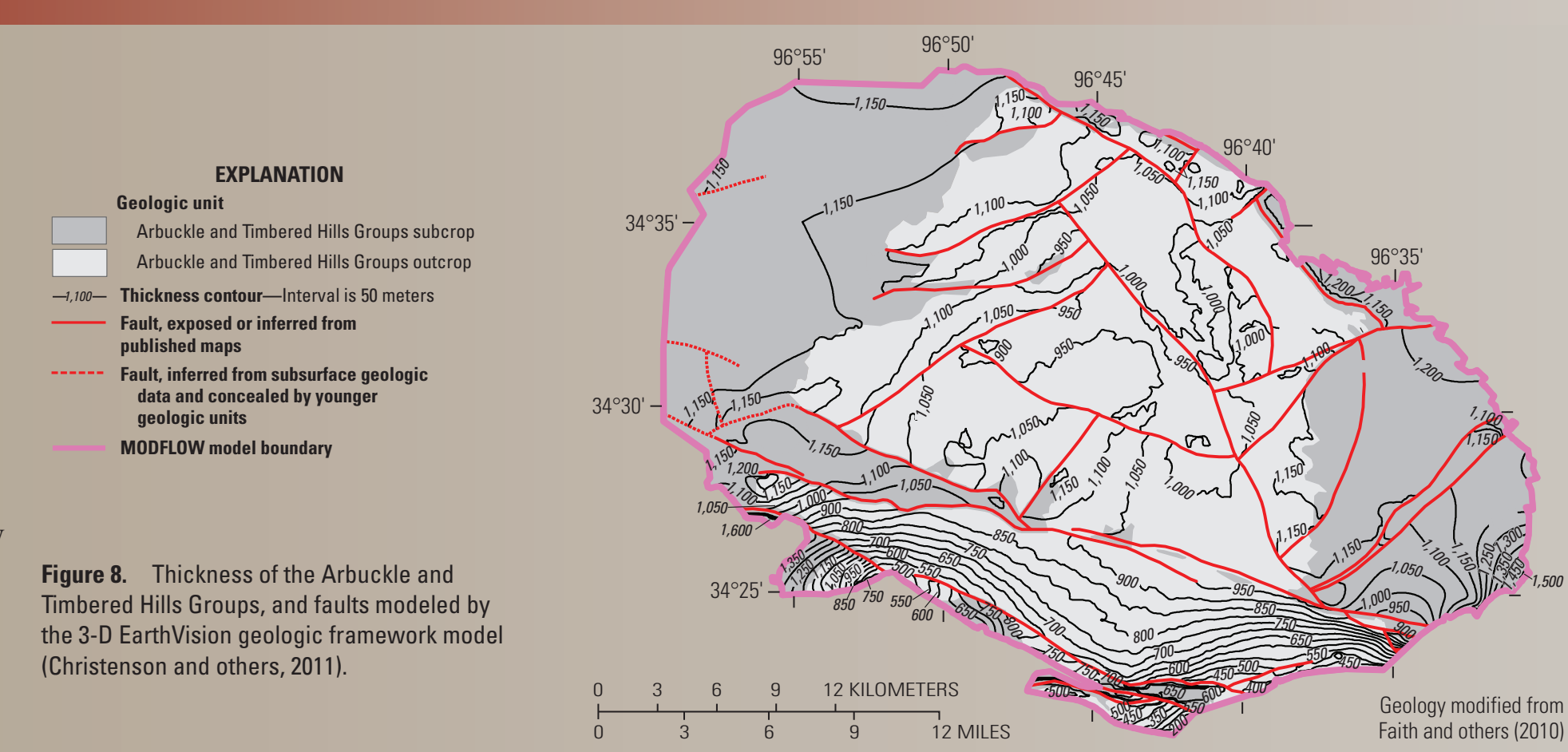

\section{Arbuckle-Simpson MODFLOW Model}

A MODFLOW groundwater-flow model was specifically developed to simulate discharge to streams and spring in the eastern Arbuckle-Simpson aquifer (Christenson and others, 2011). Six layers of 200-meter cells were used to represent the aquifer over a total area of 1,002 square kilometers. The resulting simulated potentiometric map (fig. 9) represents over 25,000 data points and agrees woll with water lovel measurements ade in the fich Ber lager would cause decreased stream the the model was optimized to sin the the effects on the streams with the largest streamflows: Blue River and Pergest streamflows: Blue River and Pennington
Creek. Model simulations of the effects of distributed withdrawals on daily streamflow show that increasing withdrawal of groundwater from the aquifer would result in reduced streamflow and in reduced discharge to streams and springs in many locations.

$$
\begin{aligned}
& \text { EXPLANATIO }
\end{aligned}
$$

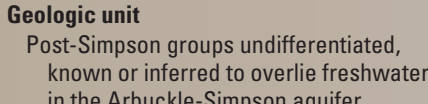

$$
\begin{aligned}
& \begin{array}{l}
\text { in the Arbuckle-Simpson aquifer } \\
\text { Simpson Group } \\
\text { Arbuckle and Timbered Hills Groups }
\end{array} \\
& \text {-920- Potentiometric contour-Shows altitude }
\end{aligned}
$$
potentiometric surface in MODFLOW layer of the Hunton anticline area (modified from

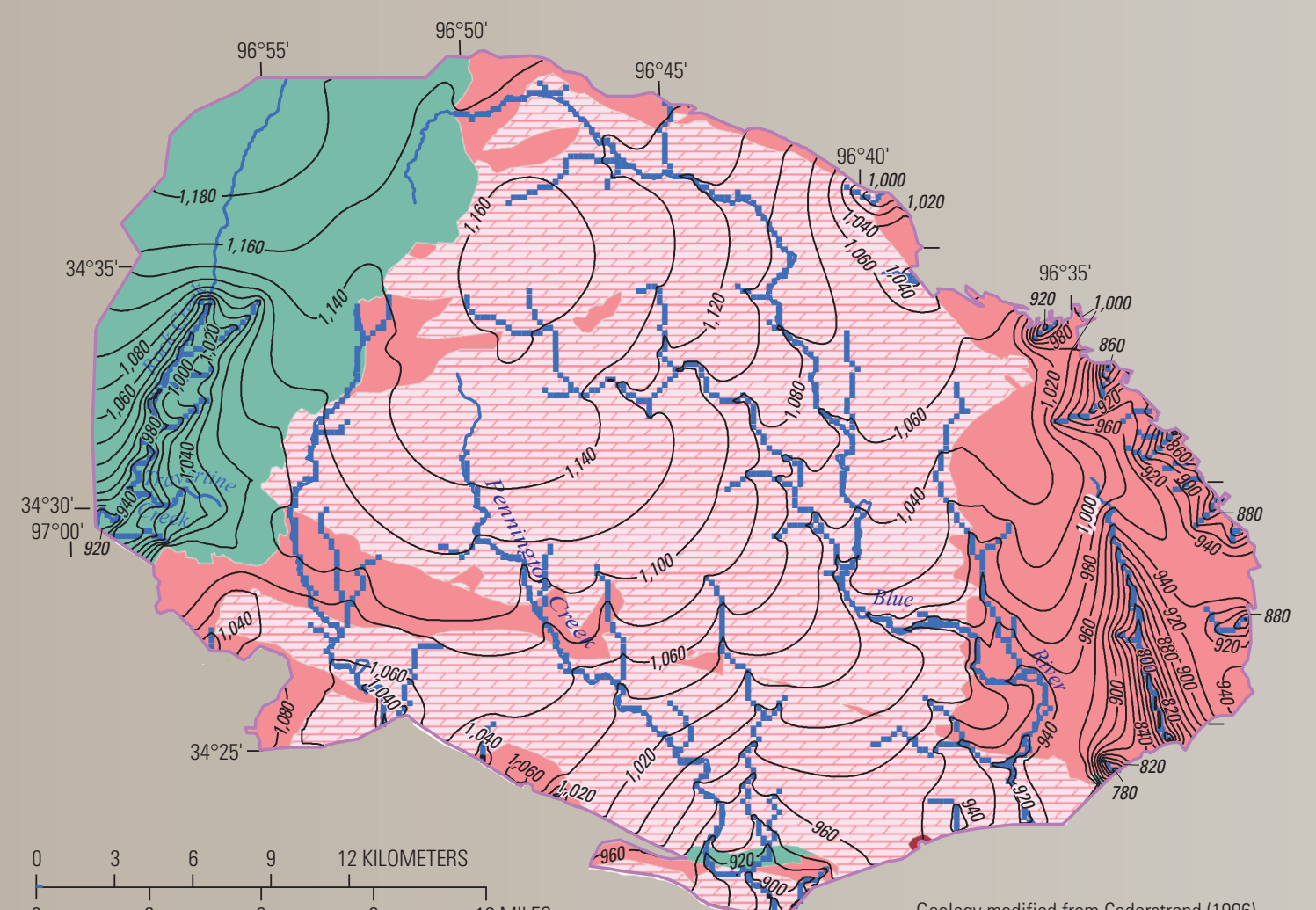

Figure 9. Simulated steady-state

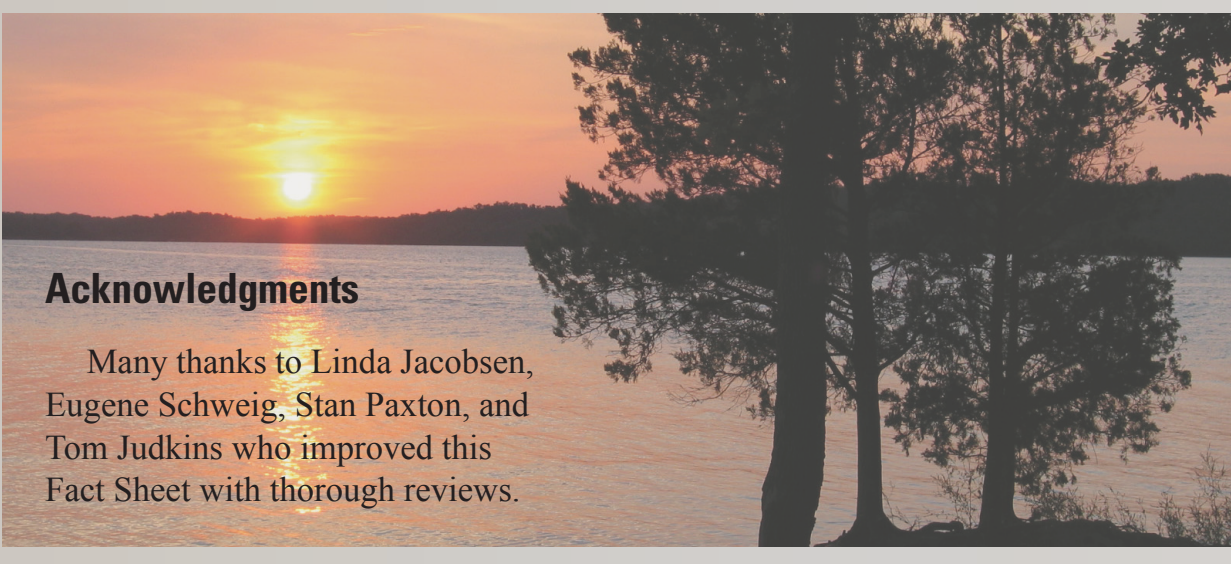

References Cited

Blome, C.D., Faith, J.R., Collins, E.W., Pedraza, D.E., and Murray, Kyle, 2004, Geologic ma compilation of the Upper Seco Creek area, Texas: U.S. Geological Survey Open-File. Texas: U.S. Geological Survey Open-File
Report 2004-1430, map with pamphlet, $21 \mathrm{p}$, scale $1: 50,000$

Blome, C.D., Faith, J.R., and Ozuna, G.B., 2006, Geohydrologic framework of the Edwards and Trinity aquifers, southcentral Texas: U.S. Ge

Cederstrand, J.R., 1996, Digital geologic map of Ardmore-Sherman quadrangles, south-central Oklahoma: U.S. Geological Survey Open-File port http:///kk.water usgs.gov/gis/geologyy). Faith, J.R., Blome, C.D., Puckette, James, and Pantea, M.P., 2011, Hydrogeology and simulation of groundwater flow in the Arbuckle-Simpson aquifer, south-
central Oklahoma: U.S. Geological Survey central OKlahoma: U.S. Geological Survey
Scientific Investigations Report $2011-5029$

104 p.
aith, J.R., Blome, C.D., Pantea, M.P., Puckette, J.D., Halihan, Todd, Osborn, Noel, Christenson, Scott, Pack, Skip, 2010, Three-dimensional geologic model of the Arbuckle-Simpson aquifer, south-central Oklahoma: U.S. Geol
cal Survey Open-File Report 2010-1123,

acobsen, L.J., Glynn, P.D.., Phelps, G.A.. Orndorff, R.C. Bawden, G. W., and Grauch, V.J.S., 2011 , Chapter 13: U.S. Geological Survey - A synopsis of three-
dimensional modeling, in Berg, R.C., Mathers, S.J. Kessler, Holgar, and Keefer, D.A., eds., Synoppsis of current three-dimensional geologic mapping and modeling in geological survey organizations: Illinos
State Geological Survey Circular 578 , p. $69-79$. State Geological Survey Circular 578, p. $69-79$.
Johnson, K.S. 1990, Geologic map of sections of the Arbuckle Mountains, Oklahoma: Oklahoma
the Geological Survey Circular 91, plate 1, accessed September 14,2012, at http://www.ogs.ou.edu
pubsscanned/CircularsPlates C9IPI.pdf. pubsscanned/CircularsPlates/C91PI.pdf.
antea, M.P., and Cole, J.C., 2004, Three-dimensional stratigraphic units within the Edwards Aquifer,
northern Bexar County, Texas: U.S. Geological Survey Scientific Investigations Report 2004-5226, Pantea, M.P., Cole, J.C., Smith, B.D., Faith, JR

Blome, C.D., and Smith, D.V., 2008, Three-dimensional geologic model of complex fault structures in the Upper Seco Creek area, Medina and Uvalde Counties, south-central Texas: U.S. Geological Survey Scientific Investigations Report 2008-513,
CD with 9-p. pamplet

Thith, B.D., Smith, D.V., Hill, P.L., and Labson, V.F.,
2003. Helicopter electromangetic and magnetic sur vey data and maps, Seco Creek area, Medina and

\begin{tabular}{|c|c|}
\hline \multicolumn{2}{|c|}{ By Charles D. Blome and David V. Smith } \\
\hline \multicolumn{2}{|l|}{ Contacts: } \\
\hline Charles D. Blome & David V. Smith \\
\hline U.S. Geological Survey & U.S. Geological Survey \\
\hline MS 980, Box 25046, DFC & MS 964, Box 25046, DFC \\
\hline Denver, C0 80225 & Denver, C0 80225 \\
\hline \multirow{2}{*}{\multicolumn{2}{|c|}{ This fact sheet is available online at $h t p p: / / p u b s . u s g s . g o v$}} \\
\hline & \\
\hline
\end{tabular}

Open- Cile Report to3-226, 5 p p., 1 pl.
Smith, B.D., Smith, D..., Desczz-Pan, Maryla, Blome, C.D., and Hill, Patricia, 2011, Helicopter electromagnetic and magnetic geophysical survey data, Hunton anticline, south-central Oklahoma: U.S. Geological $29 \mathrm{p}$. 